Portland State University

PDXScholar

$12-9-2017$

\title{
Translation and Transformation: Uncovering the Source of Alchemy's Association with Magic through a Study of its Translation into Latin in the High Medieval Period
}

Morgan Taylor Greer

Portland State University

Follow this and additional works at: https://pdxscholar.library.pdx.edu/honorstheses Let us know how access to this document benefits you.

\section{Recommended Citation}

Greer, Morgan Taylor, "Translation and Transformation: Uncovering the Source of Alchemy's Association with Magic through a Study of its Translation into Latin in the High Medieval Period" (2017). University Honors Theses. Paper 513.

https://doi.org/10.15760/honors.518

This Thesis is brought to you for free and open access. It has been accepted for inclusion in University Honors Theses by an authorized administrator of PDXScholar. Please contact us if we can make this document more accessible: pdxscholar@pdx.edu. 
Abstract: Alchemy is one of the longest lived ideas in intellectual history and one of the most habitually misunderstood. Until the 1950s historians of science considered alchemy to be pseudoscience or a facet of magic. Since than historians of alchemy have produced a considerable body of work that is mostly concerned with opposing the pseudo-scientific reputation of alchemy and instead establishing its scientific character. Alchemists made significant contributions to chemistry, theology, and medicine. Alchemy itself influenced art, literature, and pop culture. The current literature on alchemy lacks one component, a study of the source of alchemy's association with magic and relegation to pseudoscience. This research endeavors to contribute to the growing body of research on the history of alchemy by addressing this void. This research concludes that alchemy's association with the supernatural and pseudoscientific occurred during the process of its translation and transmission from Arabic scientific texts to Latin in the high medieval period. 
Translation and Transformation: Uncovering the Source of Alchemy's Association with Magic Through a Study of its Translation into Latin in the High Medieval Period

\author{
By \\ Morgan Taylor Greer \\ A thesis submitted in partial fulfillment of the \\ requirements for the degree of \\ BACHELOR OF ARTS WITH HONORS \\ in \\ HISTORY
}

Portland State University 
To my mother and grandfather, without whom this would not have been possible. 


\section{Acknowledgements}

Thanks are owed for those who assisted in the completion of this project. First I must express overwhelming gratitude for Thomas, for his unflagging patience as a sounding board for ideas, employment as an editor, and unwavering encouragement throughout this process. I must again, note that without my mother this would never have been possible. She has been always the voice in my head reminding me I can do better, and no matter how tired I am, to never give up. My grandfather deserves additional mention for his continued support throughout my life and academic career. His love and generosity throughout my life and long career as a student made this possible. The two of them instructed me in my faith, which has sustained me the many times I was overwhelmed and discouraged.

My friends are due thanks, especially Hannah and Celina. They too have been unwavering in their enthusiasm and support for me and my work. I am also grateful to one person who is no longer in my life; his influence made me reach higher and pushed me to transfer to Portland State.

Special thanks goes to the Honors College, for their flexibility for my unique situation. Last but so much greater than least, I am abundantly grateful for my advisors, who have patiently endured the many setbacks of this project and allowed me to go perhaps wider than I should have gone, pushed me to think more creatively and edited each subsequent draft with thought and care. 
Table of Contents

Acknowledgements

i

Chapter 1 Alchemy Explained 1

Chapter 2 Translation in Context 19

Chapter 3 Translation and Transformation 35

Bibliography $\quad 48$ 


\section{Chapter 1}

\section{Alchemy Explained}

Though it is called many things and has multifarious associations, alchemy is most accurately wedged into the category science. The definition and social understanding of science has changed over time, and there is no category or term in our modern scholastic lexicon that suits everything that alchemy was. The mystique of alchemy- the depth of complexity in understanding, explaining and even practicing it- has been a double edged sword for alchemy. The purposeful snares of allegory and legion of code words borrowed from mysticism, religion, and astrology in alchemical literature make it seem distant and familiar to modern eyes. In the long term, alchemists drive to obfuscate and glorify their work has ensured both perennial fascination and persecution. Alchemists have been accused of being charlatans, soothsayers, sorcerers, con artists, and occasionally of being malodorous. The effect of these accusations is exemplified in the early years of chemistry as a formal academic discipline. Near the end of his career, in 1718, the 'Swiss Hippocrates' Herman Boerhaave gave a speech after being elected to the chair of chemistry at the University of Leiden. Addressing his fellow professors, he gave a speech entitled "Purging Chemistry of its Errors," in which he said, "I must talk about chemistry! About chemistry a subject disagreeable, vulgar, laborious, a subject far from the affairs of intelligent people, and ignored or considered suspect by the learned." In order to establish itself 
with any credibility after the Scientific Revolution, chemists were quick to sever chemistry’s relationship to alchemy. ${ }^{1}$

Borhaave's speech paints a grim picture for alchemy, but it was not always a sociointellectual pariah, nor did that distinction hinder its influence. Herman Boerhaave practiced alchemy in secret, while conducting himself as a chymist at the university. ${ }^{2}$ In the past century it has come to light that Isaac Newton spent much of his free time and considerable energy attempting to achieve alchemical transmutation. Some scholars estimate he wrote more than a million words on the subject. ${ }^{3}$ Leonardo Da Vinci has also been shown by recent scholarship to have used alchemical processes for gilding things and making paints from chemical reactions. ${ }^{4}$ The eccentric Swiss doctor Theophrastus von Hohenheim, better known as Paracelsus (14931541), was enamored with it as well, and incorporated it into his medical work. ${ }^{5}$ The founder of analytical psychology, Carl Jung, wrote extensively on alchemy as well, though he added a psycho-spiritual element that is almost certainly his own invention. ${ }^{6}$ Mozart's opera Die Zauberflote is likely an alchemical allegory. ${ }^{7}$ Alchemy has appeared in literature as well, from Chaucer's Yeoman's Tale to Harry Potter and the Philosopher's Stone (this was J. K. Rowling's original title, and remains the title in the U.K. American publishers believed children would be

\footnotetext{
${ }^{1}$ Lawrence M. Principe "Alchemy Restored." Isis 102, no. 2 (2011): 305-12.

${ }^{2}$ Ibid.

${ }^{3}$ Isaac Newton, The Key, trans Betty Jo Dobbs ed. Stanton J. Linden. The Alchemy Reader: From Hermes Trismegistus to Isaac Newton (Cambridge: Cambridge University Press, 2003) 243-247.

${ }^{4}$ Ladislao Reti "Parting of Gold and Silver with Nitric Acid in a Page of the Codex Atlanticus of Leonardo Da Vinci." Isis 56, no. 3 (1965): 307-19. William R. Newman Promethean Ambitions: Alchemy and the Quest to Perfect Nature. (Chicago: University of Chicago Press, 2004) 121-125.

${ }^{5}$ Pamela H. Smith, The Business of Alchemy: Science and Culture in the Holy Roman Empire (Princeton, N.J.:

Princeton University Press, 1994) 45.

F. Sherwood Taylor, The Alchemists. (New York: Collier Books, 1962), 154.

${ }^{6}$ Ibid., 124, 178.

${ }^{7}$ For an extensive treatment of the opera as an alchemical allegory, see M. F. M. Van Den Berk, The Magic Flute, Die Zauberflöte: An Alchemical Allegory (Leiden; Boston: Brill, 2004).
} 
deterred by the word "philosopher"). ${ }^{8}$ Eminent figures of theology of no less influence than Roger Bacon, St Thomas Aquinas, and Martin Luther discussed it in their writings, as did Dante Alighieri in his Divine Comedy, who relegated alchemists to the eighth circle of hell alongside counterfeiters and forgers. ${ }^{9}$

Though it has been of perennial interest in scholarship and the public imagination, until the 1950s alchemy was largely relegated to the status of supercilious pseudoscience, of little interest for historians. This research seeks to add to the emerging body of scholarship steadily illuminating what alchemy was and what alchemists actually did in their laboratories. In addition this research will explore a topic in the historiography that remains incomplete: the gulf between the reality of alchemy and the reputation it has acquired.

The debate about the origin of alchemy has enjoyed longevity and is more extensive than space allows, but a brief summary is necessary. Ancient alchemical traditions can be found in India, China, Egypt, and Greece. How much these traditions influenced each other and the degree to which they may be related is one of the points of greatest contention. The majority of scholarship agrees that while the Indian and Chinese traditions certainly held some influence, the alchemy which was practiced in the empires and premodern states of the Arabic world and Europe is best classified as western alchemy, while the Chinese and Indian traditions are relegated to eastern alchemy. ${ }^{10}$ As this research focuses on the history and influence of western alchemy, its origins are the best starting place. The origins of western alchemy can be placed with some accuracy around the third century BCE in the cosmopolitan world of Hellenistic

\footnotetext{
${ }^{8}$ Edgar H. Duncan, "The Literature of Alchemy and Chaucer's Canon's Yeoman's Tale: Framework, Theme, and Characters," Speculum 43, no. 4 (1968): 633-56.

Lawrence Principe, The Secrets of Alchemy (Chicago; London, University of Chicago Press, 2013 ), 1.

${ }^{9}$ Principe, The Secrets of Alchemy, 178-179.

${ }^{10}$ There are many sources to consult on this topic. See R. J. Forbes, "On the Origin of Alchemy," Chymia 4 (1953): 1-11; Arthur John Hopkins, "A Defence of Egyptian Alchemy," Isis 28, no. 2 (1938): 424-31; F. Sherwood Taylor, The Alchemists (New York: Collier Books, 1962), 22-28; Principe, The Secrets of Alchemy, 5.
} 
Egypt, where Greek philosophy united with Egyptian metallurgical techniques. Unfortunately this period in alchemy's history remains rather cloudy; very few documents survive. Two papyri from the third century, now called the Stockholm and Leyden papyri for the cities and libraries they reside in, paint a picture of the technical tradition alchemy built on. The Leiden papyrus provides recipes "For Giving Objects of Copper the Appearance of Gold" and "Doubling of Gold" The recipes boast that their products "will deceive even the artisans," and that "It is difficult to detect the fraud." While Egyptian metalworkers created things that looked like gold, they do not seem to have had any intention of attempting to actually turn other metals into gold. The recipes use mercury, salt, vinegar, and clay vessels, and they are not careful to explain every detail of the procedures but instead reference ingredients and procedures with a familiarity they seem to expect in the reader. The belief that this work was something greater, that it was possible to turn copper into gold, required the infusion of Greek philosophy, occurred at some time likely in the same century as these papyri, a union that would produce something between art and science. ${ }^{11}$

Some etymology is prudent here. The terms art and science have changed considerably over time. In the premodern world, art was connected to the modern concept of artisan. Any technical craft could be an art. Science was nearly interchangeable with the term philosophy; either is best described as a collection of theories or a system of belief well supported by written authorities or argument. The development of the experimental method is visible throughout the high Middle Ages, and indeed within the historiography of alchemy itself; but it did not exist or dominate science as it does today. Science was also missing the modern distinction between applied and theoretical. In the absence of any experimenting to speak of, everything was

\footnotetext{
${ }^{11}$ Principe, The Secrets of Alchemy, 13.
} 
theoretical. Natural philosophy is a term sometimes used for science in this period and it is fitting since the theories about the world and scientific discourse were largely arrived at through observation. $^{12}$

The term alchemy is even more fraught. The Art, as it has been historically called, was modified in name, theory, and practice as it moved between languages, cultures, and it lasted through centuries. Alchemy has been chēmia or chymia, a Greek term with a connotation of metallurgical work. It became Al-kimiyā after its translation to Arabic, where it acquired Islamic influences, new theories, expanded recipes and technologies. It would then be translated into Latin and become alchymia, alchemia, and alchimia. In its Latin iteration alchemy not only retained popularity but was continuously expanded from the medieval period to the Scientific Revolution. A restrictive association to making gold was a relatively modern development, dating as late as the nineteenth century. The pursuit of making gold has a term of its own, chrysopoeia. ${ }^{13}$ While this pursuit was persistently central to alchemy throughout its long history, the modern association obfuscates the complexity of these alchemies, complexities too great to be fully delineated here. They are roughly collapsible into five epochs with theories, practices, and innovations characteristic to each: Greek/Egyptian, Arabic, Latin, Renaissance/premodern, and modern. In achieving the ends of this research; examining the acquisition of alchemy's association with magic and distinction as a pseudoscience, the Greek/Egyptian, Latin, and Arabic traditions are the most critical.

\footnotetext{
${ }^{12}$ David C. Lindberg, The Beginnings of Western Science: The European Scientific Tradition in Philosophical, Religious, and Institutional Context, Prehistory to A.D. 1450, 2nd ed. (Chicago: University of Chicago Press, 2007), $1,2,50$.

${ }^{13}$ William R. Newman, and Lawrence M. Principe, "Alchemy vs. Chemistry: The Etymological Origins of a Historiographic Mistake," Early Science and Medicine 3, no. 1 (1998): 32-65.
} 
The natural philosophy in vogue at the time of alchemy's inception and for some time after was Greek; Plato, Aristotle, and Galen were the most influential thinkers. It was Aristotle's theories of change, matter, and metals that would provide a bedrock for alchemical theory. He described an orderly world, where anything organic, anything not man-made, had a nature, and all natural things within the cosmos behaved in predictable ways according to their natures. In this worldview, how and why something changes was reduced to determining its nature. In Aritsotle's theory of form and matter, all objects were made of an unseen, unchanging, base something. The form of an object was its properties, classically referred to as accidents: its color, weight, taste, shape, and texture. Everything is a composition of four elements: earth, water, air, and fire. These were further reduced to something he called sensible qualities; hot-cold and wetdry. Aristotle's theories provided a complete mechanism for natural objects to undergo change. For example, when water is boiled, its wet qualities give way to heat and it is transmuted into air. The base something, a composition of the four elements unique to each thing, remained the same while the form changed. ${ }^{14}$

Aristotle argued that metals were formed within the earth of two exhalations, one dry and smoky, and the other wet and steamy. ${ }^{15}$ An influential early alchemist, Zosimos of Panopolis (third century BCE), was probably the first to connect these theories to alchemy, and is often credited as the creator of the mercury-sulfur theory of metallic composition. ${ }^{16}$ As a general rule, alchemists believed the dry exhalation to be sulfur, the wet to be mercury, and that all things metallic were composed of some mixture of the two, all the way up to the eighteenth century. This theory was not founded completely in conjecture but was empirically promising. In the

\footnotetext{
${ }^{14}$ Lindberg, The Beginnings of Western Science, 51-56.

${ }^{15}$ Aristotle, "From the Meteorology," trans, E. W. Webster, ed. Stanton J. Linden, The Alchemy Reader: From Hermes Trismegistus to Isaac Newton, 35-36; Lindberg, The Beginnings of Western Science, 51-56.

${ }^{16}$ Principe, The Secrets of Alchemy, 35.
} 
alchemical laboratory the alchemist would have observed some metals like iron or copper give off a sulfurous smell when powdered and dropped into fire. Others such as tin and lead melt very easily and are nearly identical to mercury in this state. ${ }^{17}$ Base metals were believed to be the result of impure exhalations, an improper balance of elements or some combination of these, while noble metals were believed to come from a perfect combination of pure exhalations. ${ }^{18}$ For the alchemist, the distinctions made perfect sense. Not only did they align with Aristotle, but they seemed to be validated in their laboratories. Because base metals rust and corrode, it is therefore logical that they are of an inferior composition to noble metals, which are not only rare and beautiful but withstand corrosion. It could be logically inferred that iron and copper, with their sulfurous smells and resistance to melting, are likely more dry and composed of more sulfur, while tin and lead, easily melted and resembling quicksilver, are more wet and composed of more mercury. ${ }^{19}$

At some point in the second century BCE, scholars familiar with Greek theories and the kinds of technical processes in the Stockholm and Leyden papyri decided that they could do more than make copper look like gold; they could manipulate the matter to incur changes in form and could make copper become gold. These early years of alchemy are somewhat murky. Texts, names, and procedures have survived to the present day and paint a picture, but an opaque one. Of the few named alchemists, there is of course Zosimos as well as the works attributed to one Mary “the Jewess." Zosimos references Mary often as an ancient authority, making her place in time harder to determine but likely before Zosimos. Mary "the Jewess" is believed to have invented a method for slow, even heating of substances, influential not only to alchemy but to

\footnotetext{
${ }^{17}$ Principe, The Secrets of Alchemy, 36.

${ }^{18}$ Sherwood F. Taylor, The Alchemists (New York: Collier Books, 1962), 17-19.

19 Principe, The Secrets of Alchemy, 36-37, 108-109.
} 
cooking, as in the bain-marie or bagno marie of French and Italian cooking. ${ }^{20}$ Zosimos describes this as a cold still, which remained popular up to the eighteenth century. Distillation was likely invented by these early alchemists. The texts describe not only distillation, but sublimation, fixation, and filtration, processes that would form the core of alchemical work. Alchemists used these processes to volatilize the substances they worked with and entrap them in various apparatus, often glass coated in flour paste to prevent vapors, or spirits as they called them, from escaping. Metals were enclosed and heated in these apparatus where spirits appeared to act on the metals. ${ }^{21}$ The Greek/Egyptian corpus, though limited in texts available to the modern researcher, constituted a body of work which was translated into Arabic, where a new crop of alchemists would add additional layers of intricacy and continue to expand the Art.

In contrast to the Greek/Egyptian tradition, Arabic alchemy is clearer and there are more surviving documents. Alchemy was translated into Arabic around the end of the eighth century at the beginning of a golden age of Islamic thought during a mass translation movement. Arabic scholars expanded on the mathematics, philosophy, medicine, and alchemy that they translated from Greek, Persian, and sometimes Sanskrit. ${ }^{22}$ This is where some influence from eastern alchemy is likely, but difficult to pin down. Though there are more alchemists to choose from at this time and place, Jabir ibn Hayyan and Al Razi were arguably the most significant. Jabir ibn Hayyan (eighth century CE) may or may not have existed, and the name has certainly been borrowed, but the Arabic texts under this name provide a wealth of recipes and a window into the theoretical work of Arabic alchemists. Alchemists did not borrow strictly from Aristotle, but compiled Greek thought and developed theory distinctive to alchemy itself.

\footnotetext{
20 Principe, The Secrets of Alchemy, 16.

21 Taylor, The Alchemists, 27-29, 35-41

22 The translation movement and translation of alchemy will be discussed in detail in the succeeding chapter.
} 
Jabir compiled the work of the physician Galen of Pergamon (BCE 129-99) with the theories of Aristotle. Galen's theory of medicine has proven to be long lived and will likely be familiar to the reader. According to Galen, the body had four humors: blood, phlegm, yellow bile, and black bile. A healthy body had all four in perfect balance, while a sick one did not. Galenic medicine prescribed introducing what was lacking to create equilibrium and bring the body back to health. Jabir classifies metals like bodies; noble ones are healthy, they are in perfect equilibrium. Base metals are sick, out of balance, and need treatment. He devised a system of treatment for metals similar to treatments for the human body. Each metal was believed to have its own intricate composition of the four elements: in lead cold and dry were believed to be dominate, while gold was believed to be mostly hot and wet. According to Jabir's theory, if the proper corrective remedy of hot and wet were applied to lead it would correct the imbalance and effectively transmute it into gold. Jabir advises that alchemists should use the various techniques at their disposal; sublimation, distillation, coagulation, fixation, should all be employed to distill substances to their base matter, and create remedies for the sick metals to bring them into balance. The remedies were called al-iksīr after the Greek xerion, a word for a medicinal powder. Its subsequent translation into Latin and English rendered the word elixir. ${ }^{23}$ Though the theory of metals would shift, and subsequent alchemists simplified Jabir's intricate methods to one singular elixir, his medical approach to metals stayed relatively constant. The elixir was often called "the medicine," and frequently by its more famous epithet: the philosopher's stone.

In the work of Al Razi (854-925 CE) we find a detailed description of what alchemists did in their laboratories. He was an alchemist, doctor, and philosopher, and his work, The Secret

\footnotetext{
${ }^{23}$ Principe, The Secrets of Alchemy, 37-39. E. J. Holmyard's translation of Jabir's work provides a detailed exploration of his methods and the texts themselves, see E. J. Holmyard, The Works of Geber (London and Toronto: J. M. Dent; New York: E. P. Dutton, 1928).
} 
of Secrets, betrays his medical training in its precision and frank descriptive style. Some scholars have credited Razi with developing the laboratory manual as a concept. ${ }^{24}$ Razi divides substances into three categories, animal, vegetable, and mineral. The minerals are broken down a second time into spirits, metals, stones, vitriols, boraxes, and salts. Here we may see the influence of the Greek/Egyptian tradition in the concept of spirits. Mercury and sulfur are relegated to the spirits category, while gold, silver, copper, tin, lead, and iron are classified as metals. Razi describes not only salt but bitter salt, mountain salt, salt of ashes, and salt of lime. He doesn't refer to one sulfur but to various sulfurs, one glassy and yellow, one white, one grainy and yellow, one white and mixed with dust, and not suited to alchemical work. ${ }^{25}$ The vegetable category is of little interest to the alchemists, and Razi does not elaborate, saying “...they make little use of them, the best of those that are useful are the trees with the long seeds." Animal substances are described more favorably, he says, "From these the adept prepare their elixirs." There are ten of these: hair, skulls, brains, bile, blood, eyes, milk, mussels, urine, horns, and eggs. ${ }^{26}$ As macabre as the litany of animal substances appears to the modern reader, the vast array of ingredients is logical from the perspective of the alchemist. Creating the elixir requires a combination of whatever elements were lacking or counterbalancing whatever was overly abundant in the metal to bring it to perfect health, to transmute it. The long list of substances gave the alchemist many avenues to reach the elixir.

Razi's laboratory was replete with not only substances, but the apparatus to act on them. The equipment of the alchemist is categorized as either for smelting metal, or for working with substances. They used smelting ovens, fire tongs, crucibles, and crushers for metals. They used

\footnotetext{
${ }^{24}$ Gail Taylor, "Al-Rāzī's "Book of Secrets": The Practical Laboratory in the Medieval Islamic World” (Master's thesis, California State University, Fullerton, 2008), 1-5.

25 Taylor, “Al-Rāzī's "Book of Secrets,” 115-116.

${ }^{26}$ Ibid., 111-115, 125.
} 
curcurbits (a gourd shaped flask, part of a still), alembics (a now obsolete form of a still, also gourd shaped with a long beak and a cap), vessels, stoves, beakers, flasks, vials, and grinding plates. With the laboratory properly stocked with equipment and substances, the alchemist would apply these materials in sublimation, distillation, calcination, coagulation, and fixation in preparing the elixir and manipulating matter to their purposes. Here is an example, in a recipe for the transmutation of copper into silver.

21. (E) Another way. You take a ratl of solidified mercury and a ratl of vitriol and an equal amount of glass, and as much roasted salt as the entire amount, and grind it with white vinegar on a grindstone for one day, then roast it overnight and in fact do this three times with a light fire, and place it in an aludel and take the moisture away and let is sublimate three times, until the whole is sublimated white and dead. Then soak it with water of tin or of black lead and of silver, that is dissolved as well, and roast it seven times, and when it is improved until it is stable, runs off the text table, and does not smoke [G 19], then cast one dirham on 50 dirhams of copper and change it into white silver as God wills. ${ }^{27}$

Razi's procedure is reminiscent of an experiment, but of artisanal work as well. His measurements are exact and his familiarity with the substances used is clear. The works of Razi and Jabir would influence Alchemy's next iteration, after its translation and transmission into Latin.

The Art would prove to be long lived in its time on the European continent. Alchemy evolved until the scientific revolution when it split into alchemy and chemistry, as was briefly explored at the outset of this research and cannot be elaborated on here. ${ }^{28}$ Medieval alchemy is central to this research, where we find considerable continuity with the Arabic tradition, not only in theory and practice, but in that troubling habit of pseudonyms. Just as multiple alchemists

\footnotetext{
${ }^{27}$ Taylor, "Al-Rāzì's "Book of Secrets," 144.

${ }^{28}$ For an in-depth treatment of alchemy in premodern Europe see Pamela H. Smith, The Business of Alchemy: Science and Culture in the Holy Roman Empire (Princeton, N.J.: Princeton University Press, 1994), 45.
} 
borrowed the name Jabir, there are very few medieval alchemical texts under the name of the actual author. Here we come to a debate in alchemy more contentious than its origins, the Geber problem. Jabir was transliterated into Latin as Geber, and the texts bearing that name advertise themselves as translations from the Arabic. They were believed to be genuine translations until the late nineteenth century, when scholars began to analyze the Arabic Jabir and the Latin Geber and found inconsistencies. Current scholarship holds that Geber was likely a Latin alchemist, possibly one Paul of Taranto, while Jabir was multiple Arabic alchemists. ${ }^{29}$ We will accept Geber's work as part of the Latin alchemical tradition, and so study The Summa Perfectionis for the wealth of information it provides. The influence of earlier theories is clear in his perception of the work itself, as he says, "these imperfect bodies are not reducible to sanity and perfection, unless the contrary be operated in them...therefore they must be prepared, superfluities in them removed, and what is wanting supplied." ${ }^{30}$ In supplying what is wanting, he vehemently disagrees with Razi in the use of animal, plant, and other non-mineral substances, saying, "they are reviled into eternity, for they have left behind the blasphemies of their error; and they have poured out malediction upon the philosophers." ${ }^{31}$ Here the Summa reveals a few things. There is a distinct reverence for the past, a feeling that alchemy was connected to the "philosophers" (Greek philosophers on whom science was based at the time), but also that alchemists believed themselves to be philosophers. It is also quite obvious that alchemy was not static.

The medieval period of Latin alchemy is in many ways marked by alchemists' borrowing from their predecessors. The Summa attests to this too, as recent scholarship holds that much of

\footnotetext{
${ }^{29}$ William Newman is the authority on the Geber problem and has argued most vociferously for the authorship of Paul of Taranto, see William R. Newman, The Summa Perfectionis of Pseudo-Geber: A Critical Edition, Translation and Study (Leiden; New York: E. J. Brill, 1991) 57-103. Many Arabic scholars have continued to argue that Geber is Jabir; see Ahmed Al-Hassan, "The Arabic Origin of Jabir's Latin Works," Journal for the History of Arabic Science 10 (1994): 5-11.

${ }^{30}$ Holmyard, trans., The Works of Geber, 5.

${ }^{31}$ Newman, The Summa Perfectionis of Pseudo-Geber: A Critical Edition, Translation and Study, 651-52.
} 
the Summa was borrowed from the works of al Razi and, of course, Jabir ibn Hayyan. ${ }^{32}$ Despite liberal liberating and repurposing of the ideas of their predecessors, Medieval Latin alchemists contributed a new theory. Geber relegates alchemical work to minerals only, and defers the substance of minerals largely to mercury in what is known as the "mercury alone" theory. ${ }^{33}$

Latin alchemists also ascribed an order of operations to their work. The Summa attests to it, as does a text claiming to be written by Albertus Magnus in yet another example of spurious authorship. Pseudo Albertus Magnus writes “...it should be done according to the usage of the art: first in collecting [supplies], second in sublimation, third in fixations, fourth in calcinations, fifth in solutions, sixth in distillations, seventh in coagulations, and so in on [ sic ] order." ${ }^{34}$ In this text we find another subscriber to the mercury alone theory, which would coexist with the mercury-sulfur theory for the remainder of alchemy's life. Pseudo Albertus disagrees with Geber in his limitation of almost exclusively mineral substances. He lists twenty-two substances, most of which are minerals and salts, but including urine, vinegar, eggshells, and eggs. Within this text we also find an intimate familiarity not only with substances and apparatus but the pitfalls of the alchemical laboratory as well. Pseudo Albertus warns, "Vessels are broken by the heat of the fire, as happens oftener when the clay is not good or they [the vessels] are not well baked. And when they break to pieces, white smoke at once appears...hence when the vessels smoke let them be taken from the fire at once or else the sublimation will be lost. ${ }^{35}$ Pseudo Albertus has obviously seen this before.

\footnotetext{
${ }^{32}$ Ibid., 214-215.

${ }^{33}$ Newman, Promethean Ambitions: Alchemy and the Quest to Perfect Nature, 73-74.

${ }^{34}$ Albertus Magnus, trans. Sister Virginia Heines, S.C. N., ed Stanton J. Linden, The Alchemy Reader: From Hermes Trismegistus to Isaac Newton (Cambridge: Cambridge University Press, 2003), 103.

35 Albertus Magnus, trans. Heines, ed. Linden, The Alchemy Reader, 105-109.
} 
The hazards of alchemy consisted of not only exploding vessels, but the occasionally demanding and unsavory nature of the recipes. Though Geber rejects the litany of lurid 'animal' substances Razi prescribes, he does borrow from earlier texts a less than perfumed method of solution, "hence they must be joined to each other in their properties. The method of solution is two-fold, namely through warm dung and boiling water, of which the intention and effect are the same. The method of using dung is that the calcined matter be put into a glass flask...let the top be well sealed lest it should breath out, and have the flask left under warm dung for three days." ${ }^{36}$ Here Geber is again borrowing from Arabic alchemists, as can be seen in a more complicated version of this process in a text ascribed to one Khalid ibn Yazid, a supposed dethroned prince, instigator of translation, and alchemist. ${ }^{37}$ Khalid prescribes that the well-sealed vessel should be buried in:

...Very hot horse-dung, as you can get... and in this way let it digest. But when you perceive the Dung to grow cold, get other fresh Dung which is very hot, and put your Vessel therein to digest as before. Thus shall you do for the space of forty days, renewing your Dung so often as the occasion or reason of the Work shall require, and the Medicine shall dissolve of itself, and become a thick White water. ${ }^{38}$

The recipe literature was not always occupied with such malodorous work, though with the frequent usage of sulfur and burning of various mineral and animal substances we can imagine the alchemist's laboratory to have been a fragrant place. It was demanding work with many of the recipes insisting on the kind of careful attention Khalid's recipe exemplifies; as Pseudo Albertus' caution against explosions in sublimation shows, a lack of attentiveness could mean the failure of

\footnotetext{
${ }^{36}$ Newman, The Summa Perfectionis of Pseudo-Geber, 710.

37 The legend of Khalid ibn Yazid is interesting in his influence on alchemy and the likelihood that he didn't exist. He is mentioned in a ninth century text regarding the translation of Greek science and alchemy in particular, see Ibn Al-Nadīm, Muḥammad Ibn Ishāà, trans. Bayard Dodge. The Fihrist of Al-Nadìm; a Tenth-Century Survey of Muslim Culture. (New York: Columbia University Press, 1970), 581. For Khalid's role in the history of alchemy see also Principe, The Secrets of Alchemy, 29-30, 33, 52.

${ }^{38}$ Khalid ibn Yazid, trans, Salmon, ed. Linden, The Alchemy Reader, 79.
} 
the recipe and the waste of substances that were very often expensive. The alchemical laboratory was a carefully designed space where the alchemist worked diligently and carefully with exact procedures and empirically promising applied theories. Alchemical recipes and theory are, of course, largely inert as modern science has shown, but they paint a picture similar to the work of a chemist, and certainly in contrast to the description of it from the earliest chemists, namely the "sins" Herman Boerhaave referred to as "far from the affairs of intelligent people." The picture of the incompetent or conniving alchemist; the alchemist as magician painted in popular depictions of alchemy, from Boerhaave to J. K. Rowling, presents a contrast to what we find in the texts, begging the question, where did it come from?

Some explanation is to be found in the alchemical tradition of secrecy. Pseudo Albertus insists on secrecy, saying "the first precept is that the worker in this art must be silent and secretive and reveal his secret to no one. ${ }^{" 39}$ Some scholars have suggested alchemists maintained secrecy to preserve trade secrets. If it were possible to transmute metals, a population equipped with that power would be disastrous for any economy. In the time of Zosimos, the Emperor Diocletian suppressed a rebellion in Egypt and subsequently ordered all "books written by the Egyptians on the cheimeia of silver and gold" to be burned. ${ }^{40}$ Though this account is possibly legend, the likelihood of its foundation on some truth demands its inclusion in considering the alchemist's interest in secrecy.

A few early alchemists, Jabir and Zosimos included, were members of esoteric religious sects for whom secrecy and a cryptic writing style was fashionable and practical. Ninth-century Islamic records remember Jabir ibn Hayyan's life as one of constant movement. Jabir was

\footnotetext{
${ }^{39}$ Albertus Magnus, trans. Heines, ed. Linden, The Alchemy Reader, 99-109.

${ }^{40}$ Lawrence, The Secrets of Alchemy, 22.
} 
perpetually in hiding from the authorities..$^{41}$ There is also the alchemical instinct to defer to the past. One of the defining differences between alchemy and chemistry is, rather than trying to create something new, alchemists promised to reveal the secrets of the ancients. ${ }^{42}$ Subsequent alchemists likely parroted the secrecy they found in the earlier literature to lend their texts the antiquated authoritative quality they and their readers were looking for. The involvement of several prominent alchemists in esoteric religious sects, the inherent economic dangers of alchemy's promises, and the drive to seem authentically ancient gave alchemists a few reasons to purposefully obscure their work and themselves.

In keeping their secrets, alchemists were inventive. We have encountered multiple pseudonyms in this brief survey of alchemical literature. Spurious alchemical texts under names such as Moses, Plato, Aristotle, Albertus Magnus, Roger Bacon, and even the Persian philosopher and vocal critic of alchemy Ibn Sina, are numerous. ${ }^{43}$ Within the texts themselves, alchemists employed a few tactics. The tahdìd al- 'Ilm or dispersal of knowledge is evident in the Summa. In the proem Geber writes "Whatever was hidden by us in one part we have made manifest in the corresponding part of this volume, so that the achievement of this both very excellent and noble part of philosophy be made accessible to the wise." This passage was directly borrowed from Jabir, and is reminiscent of many alchemical works. ${ }^{44}$ Geber in repeating Jabir is talking about the dispersal of knowledge, the practice of writing texts out of order, inserting unrelated topics within other topics and spreading ideas and recipes between various texts. Alchemists were also fond of cryptic language, allegorical descriptions and symbolic code

\footnotetext{
${ }^{41}$ Ibid., 45. Ibn Al-Nadīm, Muḥammad Ibn Ishạā, trans. Bayard Dodge, The Fihrist of Al-Nadīm; a Tenth-Century Survey of Muslim Culture, 861-3, 868.

42 Taylor, The Alchemists, 29.

${ }^{43}$ Gabriele Ferrario, “An Arabic Dictionary of Technical Alchemical Terms: MS Sprenger 1908 of the Staatsbibliothek Zu Berlin (fols. 3r-6r),” Ambix 56, no. 1 (March 2009): 5-48. Taylor, The Alchemists, 29.

${ }^{44}$ Newman, The Summa Perfectionis of Pseudo-Geber, 633.
} 
names for substances. The code names of alchemy have been termed Decknamen, as the names of substances or processes correspond to their perceived nature. ${ }^{45}$ A medieval Islamic manuscript, perhaps best identified as MS Sprenger 1908 thanks to its indeterminate authorship and obvious compilation of other texts, provides a sort of dictionary for alchemical symbols. Gold could be "the noble silver," "the father of experience," "the wise," "the balanced," "the tomb," or "king of the bodies," though it was most frequently called "the sun". Mercury has around 50 epitaphs, some of which, such as "the life of the bodies," "the reigns," and "the author" make sense in light of alchemical theory. Others, such as "the fish," "chick of the jinn," and "the urine of the lunatics" are less easily determinable. ${ }^{46}$

In conjunction with Decknamen and dispersal of information, alchemists utilized allegory to obfuscate their work. Zosimos provides an example of alchemical allegory in his Of Virtue lessons 1-3, he writes:

Saying these things I went to sleep, and I saw a sacrificing priest standing before me at the top of an altar in the form of a bowl. This altar had fifteen steps leading up to it. Then the priest stood up and I heard a voice from above me saying to me, 'I have accomplished the descent of the fifteen steps of darkness and the ascent of the steps of light and it is he who sacrifices, that renews me, casting away the coarseness of the body; and being consecrated priest by necessity, I became a spirit. ${ }^{47}$

Here Zosimos betrays his influences, not only the philosophy of Aristotle but his gnostic persuasion as well. Gnostics believed that the human soul was imprisoned within a sinful and corrupt body, to be freed by knowledge. A belief system that drew easy parallels with the processes of alchemy; the base becoming noble through sublimation, vaporization, and spirits trapped and transformed within vessels. The metaphor was not missed by Gnostics, Muslims, or

\footnotetext{
45 Ferrario, "An Arabic Dictionary of Technical Alchemical Terms," 5-48.

${ }^{46}$ Ibid.

${ }^{47}$ Zosimos of Panopolis, trans. Taylor, The Alchemy Reader: From Hermes Trismegistus to Isaac Newton, 50-51.
} 
Christians; Martin Luther espoused high esteem for alchemy as religious metaphor. ${ }^{48}$ The allegory has more between the lines than Zosimos' influences. The fifteen steps correspond to the number of steps to procure the philosopher's stone.$^{49}$ The number of steps varied as various authors proposed different recipes for the stone. The priest is the substances of the alchemist personified, a common device in alchemical literature. As seen above in the propensity of alchemical vessels to explode, in the personification of alchemical processes, violence is a common theme. Within Zosimos's strange and fantastic descriptions, there are alchemical processes concrete laboratory procedures and careful, intricate theory. To a trained eye, the symbolism is challenging but not prohibiting. It is also easily be inferred how a suspicious and untrained eye might draw other conclusions about these texts, and how difficult it would be to translate them.

Alchemy was the pursuit of perfection in nature at the hands of man through applied theory. By modern standards it was primitive in its theories and understanding of matter, but undeniably sophisticated in its application and aims. As we have seen, alchemical literature developed a cryptic style with the intent of obfuscating alchemists themselves and their work. The inaccessibility of alchemical literature would pose problems for alchemy as it developed and moved from language to language and culture to culture. The seeds of association between alchemy and the suspicious sides of spirituality were sewn as it moved from the second to the third iteration explored here. The process of alchemy's defamation is to be found in the process of its translation and transmission from the Arabic world to the Latin one in the politically charged translation movement of the twelfth century.

\footnotetext{
${ }^{48}$ Linden, The Alchemy Reader, 22.

${ }^{49}$ For a similar usage of allegorical numbers to infer steps in the process, see Principe, The Secrets of Alchemy, 144.
} 


\section{Chapter 2}

\section{Translation in Context}

In 1571, an alchemist named Philip Sömmering received the patronage of Duke Julius of Braunschweig-Wolfenbüttel in Northern Germany. In exchange for a handsome stipend, living arrangements, a laboratory, and some gifts the alchemist agreed to produce a tincture for transmuting metals (essentially the philosopher's stone), among other things. However comfortable the arrangements were at the outset, the arrangement would prove to be short-lived. By 1574, he and his assistants were jailed after arousing the suspicion of the duchess, the sister of the duke, and other prominent voices at court. Sömmering's trial lasted over a year, during which time the alchemists were interrogated with and without torture. Over the course of that year they were accused of fraud, adultery, murder, attempted poisoning, sorcery (various charms and a spell for making themselves invisible), and stealing state papers, to name the most egregious charges.

Through torture, confessions were obtained for most of the crimes and the accused were sentenced to death. The style of execution was spectacularly gruesome, even for the age. Their skin was torn with red hot tongs, some were quartered alive, one's body was broken on the wheel 
before meeting that fate, and a singular female alchemist of the group was first burned with tongs before being strapped to an iron chair and burned alive. ${ }^{50}$ It is prudent to examine how alchemy became such a dangerous practice. Perhaps more than any other pre-modern art or science, alchemy has collected multifarious perceptions differing significantly from what it actually was. Any interested scholar looking to ascertain what alchemy really was, what alchemists believed and did in their laboratories, is embarking on an intellectual odyssey with nearly as many pitfalls and misdirections as the original odyssey. In the preceding pages we have established what it was, an important part of intellectual history, of scientific history, and something akin to a predecessor to chemistry. ${ }^{51}$ Despite its relevance to the history of science, it was not until the last fifty years that historians began to consider alchemy as more than superstitious pseudoscience. In the recent scholarship there is a conspicuous poverty of information on the twelfth-century translation of alchemy from Arabic to Latin. In examining the translation and transmission of alchemy into the Latin world, the source of its unsavory reputation with magic and fraud will be uncovered.

As far as modern scholarship has determined, prior to the twelfth century alchemy was completely unknown to the Latin world. This fact is arrived at through two points of consensus. Alchemy's translation was well recorded by medieval standards. It was conducted by one Robert of Chester on the 11th of February 1144. By this point Toledo had become the center of the translation movement so it was likely completed there. Robert prefaced his translation with a declaration of the information's novelty, saying "Since what Alchymia is, and what its

\footnotetext{
${ }^{50}$ Tara Nummedal, Alchemy and Authority in the Holy Roman Empire (Chicago, Ill; London: University of Chicago Press, 2008), 1-4.

${ }^{51}$ This title is a nuanced one, as chemistry certainly borrowed from and was influenced by alchemy, it also did its best to distance itself and developed with other influences. The best treatment of this topic can be found in the following. William R. Newman and Lawrence M. Principe, "Alchemy vs. Chemistry: The Etymological Origins of a Historiographic Mistake." Early Science and Medicine 3, no. 1 (1998): 32-65.
} 
composition is, your Latin world does not yet know, I will explain in the present book."52

Alchemy as an idea made its entrance into the Latin world at the end of the twelfth century. It was translated as one of many texts incepted from the Arabic world within the broader confines of the twelfth-century translation movement, a movement which occurred not in a vacuum but within the social, cultural, and economic developments of its age. These developments have been deemed profound enough to be labeled part of the twelfth century "renaissance" by historians.

The idea of a twelfth-century renaissance and of a Latin world or an Arabic one may be unfamiliar to the reader. The twelfth century has been termed a renaissance for its resurgence of access to learning and the inception of new information fueled the subsequent rise of a revival in poetry, increased complexity in architecture and sculpture, renewed historical writing, a revival of Latin literature, and of the sciences in general. ${ }^{53}$ All these facets of the renaissance are fascinating and important, but in this present study will be limited to providing context for the translation and transmission of information. Within this context some attention must be paid to the political currents of the period.

The conflict between Islam and Christendom is an infamous one and it is no accident that it bookends the twelfth century renaissance. In discussing these entities they are best referred to not as Islam and Christendom but as the Latin world and the Arabic world. There are a few reasons for this. They were each largely religiously unified but not completely. The Arabic world had many Christians and Jews within it, some who converted to Islam and some who did not. As the Reconquista and crusading missions of the period continued the same could be said of the

\footnotetext{
52 Ahmad Y Al-hassan, "The Arabic Original of Liber de Compositione Alchemiae: The Epistle of Marynus, the Hermit and Philosopher, to Prince Khlid Ibn Yazd.” Arabic Sciences and Philosophy 14, no. 2 (2004): $213-31$.

${ }^{53}$ Charles Homer Haskins was one of the first scholars to apply this term to the high medieval period and his work remains influential. See Charles Homer Haskins, The Renaissance of the Twelfth Century, (New York: Meridian Books, 1927), 1-6.
} 
Latin world. The geographic boundaries between Islam and Christianity constantly fluctuated. In each of these entities one of the greatest defining and uniting forces across religious, ethnic, and geographic boundaries was language.

The changes that took place during this century can be qualified as not only a renaissance but something of a revolution for their gravity. In order to fully appreciate the contrast, it is requisite to first examine the early medieval period. The early medieval intellectual world was characterized by limitation. The collapse of the Roman Empire saw the slow demise of schools and classical education. This left the monasteries as one of the only avenues of education or access to texts, and it was a limited one. Some or part of the seven liberal arts lasted on from antiquity but was by no means consistent. Monks could be reliably taught to read and write for the express purpose of reading the Bible, the Church fathers, and a few other texts. ${ }^{54}$

The library of the monastery was of no small importance as the saying of the age, "a monastery without a library is like a castle without an armory" betrays. ${ }^{55}$ The substance of an early medieval monastic library was often small enough that it could be piled on a single rug or fit in an alcove of the cloister. In the eleventh century a large library would number scarcely more than a few hundred volumes. Without the technology to make paper or mass print books, copying was laborious and (from the scribal monk's perspective) perdurable work. The considerable time and effort required to make a manuscript kept texts both rare and valuable. Up to the eleventh century a book could be exchanged for as a much as a house or a vineyard. ${ }^{56}$ At around the eleventh century, traditional Benedictine observance was replaced by Cluniac monasticism. Here reform of the church facilitated future translation efforts. Cluniac monks were

\footnotetext{
54 Lindberg, The Beginnings of Western Science, 144-155.

55 Haskins, The Renaissance of the Twelfth Century, 71.

56 Ibid., 79-81.
} 
commonly relieved of the field labor and duties in the choir in favor of copying texts. Some monasteries even considered copying texts a way to absolve sin, with absolution in each letter written. ${ }^{57}$

For the majority of the early medieval period, the inclusion of classical texts (or pagan texts as they were sometimes called at the time) was done with no small anxiety for Christian scholars. St. Augustine (354-430) had established that Christians could borrow what was true and necessary from pagan texts, advice that was taken with grave care. ${ }^{58}$ St Jerome's (347-420 CE) struggles to contain his intellectual work to the spiritual. After confessing to the reader that he has repeatedly read pagan literature, repented, and read it again, he then describes a terrible fever that afflicted him during lent. Those caring for him had begun his funeral preparations when he says "suddenly I was caught up in the spirit and dragged before the judgement seat of the judge... asked who and what I was I replied "I am a Christian.” But he who presided said: "Thou liest, thou art a follower of Cicero and not of Christ. For 'where thy treasure is, there will thy heart be also." 59 The anxiety associated with extra-theological reading in this period was enhanced by the relative lack of pagan or scientific texts. Prior to the translation movement, the majority of Greek thought was unavailable. Classical texts were available, but reading them in favor of theological texts was discouraged, and these were largely limited to Latin authors and a few translations conducted during the Roman Empire. ${ }^{60}$ In the relative political instability of this period travel was difficult, reinforcing the localism and relative ignorance outside the intellectually and culturally limited monasteries. ${ }^{61}$

\footnotetext{
${ }^{57}$ Ibid., 70-77.

58 Lindberg, The Beginnings of Western Science, 153-155.

${ }^{59}$ Jerome, Letters, trans W.H. Fremantle, ed Brian Tierney, Sources of Medieval History, 4th ed (New York: Knopf, 1983), 30-31.

${ }^{60}$ Lindberg, The Beginnings of Western Science, 145-146, 184-185.

61 Haskins, The Renaissance of the Twelfth Century, 32.
} 
This began to change with the empire of Charlemagne. In 768, Charlemagne inherited a sizable Frankish kingdom from his father. which he would expand and defend throughout his reign. The Carolingian empire was the greatest centralizing political force since Rome. ${ }^{62}$ Charlemagne saw himself as a reiteration of a Roman emperor, and as such sought to be a ruler of not only the temporal but the spiritual realms. In his bid to be the keeper and protector of the faith, Charles instituted reforms to increase the abysmal level of education among the clergy and increase scholarship in general. He founded a palace school and had his family educated there. Scholars were imported from Italy, England, and Iberia, and texts were copied and corrected in the palace school. By imperial edict, schools were established at cathedrals and monasteries throughout the empire. ${ }^{63}$ Though they did not represent a dramatic break from the substance of curriculum to be expected, the foundation of the cathedral schools provided the bedrock for the future Latin universities. ${ }^{64}$ The increases in availability of education during this period laid the groundwork for a future class of scholars outside the confines of the monastery. The implications of these reforms for the later translation movement are exemplified in the career of Gerbert of Aurillac. Educated first at the Aurillac monastery, in the 960s he traveled to Catalonia and possibly Cordoba to study Arabic science and mathematics. On his return he attended the cathedral school of Rheims. In 999 he was appointed Pope Sylvester II. ${ }^{65}$ It is likely Gerbert had something to do with the transmission of mathematic ideas as well as that vital astrological instrument, the astrolabe, which began circulating in the Latin world in the eleventh century. ${ }^{66}$

\footnotetext{
62 Lindberg, The Beginnings of Western Science, 184.

${ }^{63}$ Lindberg, The Beginnings of Western Science, 185.

Geoffrey Barraclough, The Medieval Papacy, 1st American ed. (New York: Harcourt, Brace \& World, 1968.) 4445.

64 Haskins, The Renaissance of the Twelfth Century, 368-372.

${ }^{65}$ Geoffrey Barraclough, The Medieval Papacy, 188.

66 Lindberg The Beginnings of Western Science 1450, 268.
} 
In tandem with these intellectual developments, the sociopolitical sphere of the medieval world was changing. In the earliest medieval period, the Latin Christian world was largely restricted to the former Roman empire. During and after the age of Charlemagne the church grew as missionaries spread out across the continent. The Latin world expanded with waves of conversions, bringing the north and east of the European continent into the church. ${ }^{67}$ Contrary to the strong papal monarchy of the later medieval period, the early medieval position of the Bishop of Rome was by no means established with any inherent power. Various popes attempted through new edicts, forgeries, diplomacy, and sometimes threats of divine retribution to gain control of the various competing political parties of the period. ${ }^{68}$ This was in addition to fending off attacks from Saracens, the Lombards, Vikings, and others. ${ }^{69}$ Local kings and perhaps most critically, the noblemen of surrounding Rome, jostled for supremacy. During this period no small number of popes were nominated not for their piety but ability to satisfy the personal interests of these kings and noblemen. As a result, most popes of the tenth century did not meet peaceful ends. ${ }^{70}$ By the tenth century, monastic reform movements from Burgundy and Lorraine began reshaping the church and the papacy. ${ }^{71}$ In 910 , a French nobleman established the abbey of Cluny for the express purpose of reforming what he believed to be a corrupt church.

The foundation of Cluny and reformed monasteries like them had implications further than the monastic scriptorium. The eleventh century saw a series of popes appointed for their

\footnotetext{
${ }^{67}$ Ibid., 1450, 51, Tierney, Sources of Medieval History, 70-72. Bede's Ecclesiastical History, trans A. M Sellar in ibid., 80-82.

${ }^{68}$ Barraclough, The Medieval Papacy, 53-63.

${ }^{69}$ Selected Epistles of Gregory the Great, trans J. Barmby in Brian Tierney, Sources of Medieval History. 64-69.

70 These popes met various ends, from assassination to one accused of dying of "amorous excess". The details of these accounts and the intrigue associated can be found in Geoffrey Barraclough, The Medieval Papacy, 39-63.

71"Charter of Abbey of Cluny," ed Tierney in Sources of Medieval History, 137-141.
} 
aptitude for the office rather than political intrigue. ${ }^{72}$ By 1095 Urban II was in a position of enough strength to call on the Latin world in greater unity to carry out the First Crusade. The declaration of the First Crusade speaks volumes about the success of the papacy's consolidation of power and the accompanying implications of a more unified Latin world. Urban II addressed the council of Clermont, saying "Now that you, O sons of God, have consecrated yourselves to God to maintain peace among yourselves more vigorously and to uphold the laws of the church faithfully, there is work to do." ${ }^{.73}$ The implications of a more united Latin world were, however, greater than the ability to launch a cooperative military campaign.

On the eve of the renaissance, the efforts of earlier missionaries provide their own contribution to the building sociopolitical and intellectual momentum. Increasing numbers of converts became pilgrims, traveling to holy sites once distant and unknown. Likely composed in 1140 at the height of the cult of St. James, the Pilgrim's Guide to Santiago de Compostela provides detailed descriptions of the routes to the holy shrine and the peoples encountered along the way. The cult of St. James stretched back to the ninth century, eventually taking on crusader ideology when the Saint became known as James Matamoros, the slayer of Moors. ${ }^{74}$ It can be inferred that knowledge about more than geography traveled with pilgrims. There are some records of books given as gifts to monasteries by travelers as well as travelers taking books to other places. ${ }^{75}$ From the early medieval period to the eleventh century the Latin world expanded,

\footnotetext{
${ }^{72}$ The indecencies of this development are greater than space allows here, see Decree of 1074 Council at Rome in Tierney, Sources of Medieval History, 141-143, for a primary source document detailing the ambitions and frustrations of the papacy in this period. See also Barraclough, The Medieval Papacy, 70-96.

${ }^{73}$ Fulcher of Chartres, Chronicle of the First Crusade, trans. M. E. McGinty ed. Tierney, in Sources of Medieval History, 155-156.

${ }^{74}$ The Pilgrim's Guide to Santiago de Compostela, trans. Paula Gerson, Annie Shaver-Crandell, and Alison Stones, ed. Olivia Remie Constable and Damian Zurro, Medieval Iberia: Readings from Christian, Muslim, and Jewish Sources, 2nd ed. (Philadelphia: University of Pennsylvania Press, 2012), 137-142. Bernard F. Reilly, The Contest of Christian and Muslim Spain: 1031-1157, 64-66.

${ }^{75}$ Haskins, The Renaissance of the Twelfth Century, 71-72.
} 
grew more cohesive, and more educated through the various means discussed above. Working in tandem with these mechanisms, contact with the Arabic world to the south further encouraged the movement of peoples and ideas.

Between the eighth and eleventh centuries the Arabic world came to its own ascendancy, intellectual golden age, and slow political decline. By the middle of the eighth century the Umayyad caliphate had established a sprawling empire, occupying the former territories of Alexander the Great and beyond. The caliphate covered the edge of North Africa, what is now the Middle East, parts of eastern Europe at the edges of Byzantium, and the Iberian peninsula. The Umayyad caliphate was short lived and by 750 was overthrown by the Abbasids.

Unlike their more conservative, military-minded predecessors, the Abbasids prized worldly wealth and knowledge. They established a new capital in Baghdad. It was soon famous for its lighted streets, sanitation programs, sprawling gardens, a constant influx of caravans and libraries. ${ }^{76}$ Texts were procured through conquest of cities like Alexandria and Jundishapur, in concert with diplomatic requests to the Byzantines, who had long determined the large portion of the Greek corpus in their possession to be inappropriate for Christians to study. The caliph himself sponsored the translation movement. ${ }^{77}$ The caliph ordered the construction of a massive library, which they named the Bait al Hakima or House of Wisdom. A translator working in the House of Wisdom could be paid as much as his weight in gold. ${ }^{78}$ The relative religious tolerance of the Arabic world at the time attracted Nestorian Christian scholars fleeing from the relative persecution they experienced in Byzantine territory. These scholars had in large part already

\footnotetext{
${ }^{76}$ Scott L. Montgomery, Science in Translation: Movements of Knowledge through Cultures and Time (Chicago: University of Chicago Press, 2000), 96-97.

${ }^{77}$ The political minutiae of the Abbasid translation movement cannot be fit here but can be explored in the work of George Saliba see Saliba, George. Islamic Science and the Making of the European Renaissance. (Cambridge, Mass: MIT Press, 2007).

${ }^{78}$ Montgomery, Science in Translation, 147.
} 
translated much of the Greek corpus into Syriac, a language influenced by Arabic and Greek, making it a convenient go between. ${ }^{79}$ Intermediaries were sometimes used, but many were familiar with the languages necessary to translate with skill. ${ }^{80}$

Arabic scholars wishing to learn had no formal schools to attend but rather traveled to storied masters throughout the empire. The conquest of the center of Chinese paper manufacturing at the end of the eighth century made Arabic scholarship relatively mobile and easy to disperse throughout the Arabic world. Islam had pilgrims of its own traveling to Mecca, as well as many caravans of traders carrying ivory, gold, spices, slaves, silk, olive oil, timber, and other goods from around the expanses of the Arabic world. Booksellers and libraries popped up in various cities and even along pilgrimage routes. ${ }^{81}$ The mobility of information allowed even the far-flung corners of the Arabic world to develop immense libraries. In the eleventh century, the library of Cordoba in Islamic Spain was said to have possessed 400,000 volumes. ${ }^{82}$ The reader may remember an extensive monastic library in the Latin world of this period would have held no more than a few hundred volumes.

Despite the intellectual and monetary riches of the Arabic world, its political constitution was never on solid ground. Falling and rising in succession during the ninth through to the twelfth centuries the Arabic world saw the Umayyads, Abbasids, the Caliphate of Cordoba, the Taifa of Toledo, the Almoravids and more. Each dynasty was representative of a family more akin to a clans and tribes, stretching their lineage if possible back to an association with Muhammad. A link to Muhammad, Arab blood, and desert origins was perceived of greater

\footnotetext{
${ }^{79}$ Christine Chism, "Arabic in the Medieval World," PMLA 124. (2009): 624-31. Montgomery, Science in Translation, 112-115.

${ }^{80}$ Hayrettin Yücesoy, "Translation as Self-Consciousness: Ancient Sciences, Antediluvian Wisdom, and the 'Abbāsid Translation Movement.” Journal of World History 20, no. 4 (2009): 523-57.

${ }^{81}$ Montgomery, Science in Translation: Movements of Knowledge through Cultures and Time, 103-107.

${ }^{82}$ Reilly, The Contest of Christian and Muslim Spain, 22-23.
} 
sociopolitical status than a family with little to no Arab blood, previous Christians or Jews (neoconverts) converted in newly conquered territory. The friction between these tribally and ethnically defined familial groups was particular to the Arabic world. As neo-converts grew in number the socio-political structure weakened, and various pieces of the former caliphate broke into their own political entities. By the tenth century the Arabic world would continually shrink in military and political power. This was a long, slow process with plenty of cooperation between these various caliphates through their shared language and religion. It was a decline nonetheless, facilitating the crusades as northern Christian kings in Spain saw their chance to do more than raid their wealthy southern neighbors. ${ }^{83}$ The Arabic world began its descent into political and social decline as the Latin world grew more cohesive. Alchemy's translation as far as can be discerned here was more facilitated than colored by these social and political mechanisms. As has been illustrated, the social and political mechanisms of the early medieval period induced increased movement of peoples and ideas, but they also set the stage for the crusades themselves. The clash of the Latin and Arabic worlds opened the door to further movement of information. The majority of the translation movement took place in Spanish cities recently reclaimed from Muslims for Christendom. It was the capture of these cities that gave Latin scholars access to these texts. Alchemy was translated in Spain, likely in one of the intellectually rich recently conquered cities making a brief exploration of the Reconquista a necessity.

In 1031 the caliphate of Cordoba fell into civil war and collapsed into smaller taifa kingdoms. From here the balance of power began to shift as Christian kings in the north intermarried and grew larger and more politically powerful. The Cluniacs were here too,

\footnotetext{
${ }^{83}$ Reilly, The Contest of Christian and Muslim Spain, 1-3; Thomas F. Glick, Islamic and Christian Spain in the Early Middle Ages (Princeton, N.J.: Princeton University Press, 1979), 33-50, 137-141.
} 
arranging marriages and lending money ${ }^{84}$ The conquest of the city of Toledo in 1085 was a momentous event in the Reconquista. It was a strategically valuable and a sentimental city to its captors; Toledo was the former capital of Visigoth Spain and seat of its church. It was also important for the imminent renaissance as the future center of the translation movement. This momentous conquest is also exemplary of the various social and political mechanisms at work. King Alfonso VI of Castile-Leon took the city by means more diplomatic than military. He had laid siege to it for over a year, destroying the farmland outside the walls and negotiating with the Muslim king inside. Once the king capitulated under promise of being named king of Valencia, Alfonso made special provisions to the Muslims in the city. Muslims were allowed to keep their lives and most of their possessions. It was also promised that the mosque of Cordoba would remain a mosque, but this promise was broken (according to legend) by a monk of Cluny who had been dispatched to assist in the reconquest and Alfonso's French second wife. Some scholars have speculated enticing Muslims to remain in the city after conquest was in part for their perceived worth. ${ }^{85}$

The military conquests of the Reconquista began the flow of intellectual riches accumulated by the Arabic world into the Latin one. A definitive beginning is difficult to ascertain. As observed earlier in the career of Gerbert of Aurillac, as far back as the tenth century scholars began to move south in pursuit of information. Gerbert did not speak Arabic so some translation must have already begun or the astrolabe and Arabic mathematics would have been inaccessible. It wasn't until the eve of the renaissance when the stage was set that information moved with any real momentum. The increased sociopolitical cohesion within the Latin world in conjunction with the increasing eastward interest fueled by the crusades created

\footnotetext{
${ }^{84}$ Reilly, The Contest of Christian and Muslim Spain, 25-28, 35-43.

${ }^{85}$ Smith, Melville, and 'Ubaydlī, Christians and Moors in Spain, 88-91.
} 
space for the movement of goods and information between the northern and southern spheres of the Mediterranean. Commerce increased during this period as well, fueling further movement of peoples and information. This may also be in part responsible for the rumors of treasure- as the translators came to refer to it- in the Arabic language that came over the Pyrenees.

The cathedral schools had begun to develop into the first universities with Paris, Oxford, and Bologna. The Latin world had cultivated an educated class inspiring an age of traveling scholars. Adelard of Bath (d. 1146) was one of first who retained enough prominence for his name to come down to us. He traveled extensively through the Middle East in his life, describing "Arab masters" and prescribing exploration to his fellow scholars: "it is worthwhile to visit learned men of different nations, and to remember whatever you find is most excellent in each case. For what the schools of Gaul do not know, those beyond the Alps reveal; what you do not learn among the Latins, well-informed Greece will teach you." 86 Given that the majority of Greek thought was only available in Arabic at that time, the only way to learn from wellinformed Greece was to translate from Arabic. Constantine the African, a converted Muslim who became well known as an effective doctor urged a great push to translate into Latin the "more famous things which the Arabic language contains, the hidden secrets of philosophy." ${ }^{, 87}$ One translator of the twelfth century was more blunt. Daniel of Morely attended the University of Paris until he found himself "disgusted" with his instructors. He describes his decision to travel to Toledo, saying

... I took myself away from England for the sake of academic study and spent some time in Paris, there I saw certain beasts seated in scholarly chair with grave authority. Lead styli in their hands, they reverently painted asterisks and obeli on huge immovable codices resting on two or three lecterns in front of them... These masters were so ignorant that they stood as still as

\footnotetext{
${ }^{86}$ Montgomery, Science in Translation, 144.

${ }^{87}$ Ibid.
} 
statues, pretending to show wisdom by remaining silent... and so, since these days it is at Toledo that Arabic teachings, almost all in the quadrivium, are widely celebrated, I hurried there to listen to the world's wisest philosophers. ${ }^{88}$

Scholars came from across the Latin world, from England, northern Italy, Germanic areas and from within Spain itself. By the late twelfth century Spain and especially Toledo became the epicenter of activity but translation was carried out in various places. Northern Italy, Southern France, Sicily, and to a much lesser extent the crusader kingdoms in the levant all contributed to the movement of information. ${ }^{89}$ In contrast to the Abbasid translation movement, patrons were few. Peter the Venerable, abbot of Cluny, was patron to a translation of the Qur'an in 1141, a project Robert of Chester was employed on before his translation of the Liber de Compostione Alchemaie. ${ }^{90}$ The archbishop of Toledo was also patron to some translations, as was the bishop of Tarazaona. ${ }^{91}$ In general translators worked without much to speak of in infrastructural support. There was no house of wisdom. Translators often worked in small groups with students and intermediaries. ${ }^{92}$ Some translators did not speak Arabic, though some learned it with varying degrees of success and still others originating in Spain were already fluent. Most translators relied on intermediaries in selecting and translating texts. ${ }^{93}$ The intermediaries are rarely named though one Muhammad is named in the translation of the Quran. Muslims and Jews sometimes participated, though less often as Muslims were in general vehemently opposed to the translation movement. One Muslim scholar of the early twelfth century advised his fellow Muslims not to

\footnotetext{
${ }^{88}$ Anthony Pym, Negotiating the Frontier: Translators and Intercultures in Hispanic History (Manchester: St. Jerome, 2000), 41.

${ }^{89}$ The translation movement in Spain retains a general focus because alchemy was translated there. For information on the translation movements in other places see Haskins, Studies in the History of Mediaeval Science, 130-140, 141-193, 194-222.

${ }^{90}$ Ibid., 120.

91 Montgomery, Science in Translation, 147.

92 Haskins, Studies in the History of Mediaeval Science, 11-12.

${ }^{93}$ Lindberg, The Beginnings of Western Science, 203-206.
} 
sell books to Christians, saying "...they translate them and attribute them to their own and to their bishops, even though they are Arabic works." ${ }^{94}$ Intermediaries were most often Mozarbs, or Christians who lived in Muslim territory and spoke Arabic. The intermediary would read the Arabic text out loud in Romance, the common language of Spain, and the Latin translator would hear it and write it as Latin. ${ }^{95}$ This process is undeniably clumsy and lacked the patronage and multilingual scholars of the Abbasid translation movement. Despite the hindrances to the effort, the translation movement was done with fervor. Beginning around the late eleventh century the bulk of the movement was concluded by 1220 .

It may seem curious that after a period of staunch suspicion toward pagan ideas and classical texts such a sweeping translation movement could be accomplished in the midst of a religious military conflict between the source culture and the target culture. Daniel of Morely justified the intake of pagan ideas into the Latin world in a classical, biblical context saying

Let no one be shocked if, with reference to the creation of the world, I should invoke the testimony of pagan philosophers rather than the church fathers. Although not numbered among the faithful, some of the gentiles' words are full of faith and should be incorporated into our teaching. Since our freedom from the servitude of sin has been symbolized in the Israelites' liberation from their Egyptian masters, we too have been ordered by the Lord to take the Egyptians' gold and silver vessels to enrich the Hebrews. Let us then borrow from them and, with God's help and command, rob the pagan philosophers of their wisdom and eloquence. Let us take from the unfaithful so as to enrich ourselves faithfully with the spoils. ${ }^{96}$

Here Daniel again provides evidence of the various mechanisms at work in the translation movement. Considering the anxiety St. Jerome expressed after reading Cicero it may be

\footnotetext{
${ }^{94}$ Pym, Negotiating the Frontier, 16-17.

${ }^{95}$ Abdurrahman Badawi, "The Toledo School. (Translators in Toledo, Spain during the Moorish Rule) (Al-Andalus: Where Three Worlds Met)," UNESCO Courier (1991): 40; Francisco Márquez-Villanueva, "Ways and Means of Science in Medieval Spain," European Review 16, no. 2 (2008): 145-157.

${ }^{96}$ Pym, Negotiating the Frontier, 52.
} 
shocking for the reader to encounter a medieval scholar claiming pagan authors should be studied alongside the church fathers. However neatly the comparison to the Exodus story may fit into the ideology of the crusades, Daniel's argument does more to foreshadow the response to the translation movement than to decisively neutralize the pre-existing anxiety toward pagan thought.

The Latin translation movement was colored by the social, political, and cultural mechanisms that facilitated it and the larger renaissance that developed along with it. The increase in movement of peoples and ideas triggered the largest changes in social and intellectual life in the Latin world since antiquity, a movement that was not without consequences. The movement of a multitude of new ideas moving with rapidity into a world of previous intellectual suspicion was a relative revolution. The attitude observed at the outset of this exploration with $\mathrm{St}$ Jerome did not die away completely in the face of these new ideas but remained and demanded reconciliation. After the translation movement, the scholars of the thirteenth century devoted themselves to that task. Within the context of that debate, thanks to its complete novelty and the error of one translator, alchemy came to occupy a position of utility that played the final pivotal role in its subjugation as pseudoscientific and associated with magic. 
Chapter 3

\section{Translation and Transformation}

By the thirteenth century, the majority of the work was done. An ample supply of the Arabic and Greek corpus was now available in Latin, including alchemy as a complete novelty. After centuries of limited and scarce scholastic materials, Latin scholars were overwhelmed with new material. Overwhelmed in the most literal sense, as much of this new material presented a direct challenge to not only earlier scholarship, but the worldview that had been so neatly constructed in the centuries preceding its transmission. As explored in the previous chapter, no less a revered and distant figure than St. Augustine had established the place of science as the handmaiden to theology. Science was to be studied to support Christian doctrine and assist in an appreciation and understanding of the natural world. ${ }^{97}$ The scientific and philosophical acquisitions of the translation movement were in number and in content disruptive to this ideal. In what may be called the transmission process, what was effectively the aftermath of the translation process. Alchemy was quickly defamed as the great minds of the thirteenth century

${ }^{97}$ Lindberg, The Beginnings of Western Science, 218-224. 
struggled to assimilate an overwhelming influx of uncomfortable ideas. Due to the error of one translator and the overall sociopolitical minutiae of the translation movement, alchemy was introduced at a disadvantage. The errors and influence of the translation movement in tandem propelled alchemy to the center of the debate in the transmission process while simultaneously introducing it as a fool's errand.

Though there were notable exceptions in the form of church patrons, the Latin translation movement never had the continuous, state sourced patronage or well-funded translation centers the Abbasids had. There was no House of Wisdom, there were many translators working in small groups and pairs, often with intermediaries and a limited understanding of the language, target culture, and manuscripts they translated. ${ }^{98}$ They were enriching their Latin world, themselves, and their fellow scholars as fast as they could and not without consequence. Some notable mistakes were made in the chaotic, hasty work.

In 1200, Aristotle's Meteorology was translated into Latin full the first time by Alfred of Sarechal of England, with Avicenna's (Ibn Sina in Arabic, ca 980-1037) De congelatione attached. This was logical; in this text Avicenna is discussing minerals and his work was frequently read alongside Aristotle's. He produced prolific and sought-after commentary on Aristotle. What was untenable was the omission of a distinction between the two texts in most manuscripts of this translation. The De Congelatione was effectively put in the mouth of the Philosopher and conferred the corresponding authority. Unfortunately for alchemy, it was in this text that Avicenna penned a rather caustic attack on chrysopoeia. The substance of his attack

\footnotetext{
${ }^{98}$ Much of this was dealt with in the preceding chapter. To revisit or explore further see Lynn Thorndike, A History of Magic and Experimental Science. History of Science Society Publications (New York: Columbia University Press, 1923), 75-93; Charles Homer Haskins, Studies in the History of Mediaeval Science (New York: Frederick Ungar, 1960), 3-19.
} 
originating from Alfred's translation, is supplied below so that the reader can imagine the impact of Latin scholars reading these words as Aristotle's.

Art is weaker than nature and does not equal it, however much it labor. Whence the artificers of alchemy should know that the species of the metals cannot be transmuted. They can however make likenesses and tint red with yellow, so that it seem gold, and tint white with whatever color they want, until it be very similar to gold or copper. They can also remove the dirtiness of lead, but it will always be lead. ${ }^{99}$

This manuscript began circulating barely half a century after Alchemy made its first appearance in Latin. As explored in the previous pages, before the relative intellectual revolution of the twelfth century, intellectual life in the Latin world was limited largely to an ecclesiastical class with heavily theological preoccupations. By the thirteenth century, availability of education and texts had increased to such a level that the volume and variety of those educated was dramatically increased. At the same time, the number and nature of the information available for study was altered with accompanying gravity. As a result, the thirteenth century was marked by what may be called the transmission process, the means by which materials translated are assimilated into the target culture after the work of translation is done. In the twelfth century translation movement, the bulk of translations were scientific texts. Previous to this translation the words of the church fathers and the Bible held substantial sway over science or pagan thought. The texts translated were often in direct contradiction of this long held worldview, prompting a new anxiety and concerted focus for a still largely ecclesiastical educated class. The intellectual world of the thirteenth century was preoccupied with determining the limits of science as opposed to God. Which ideas were worth keeping, which of these equally troubling and exciting ideas should be incorporated into the new universities, which were acceptable for

\footnotetext{
99 William R. Newman, The Summa Perfectionis of Pseudo-Geber: A Critical Edition, Translation and Study (New York: E. J. Brill, 1991) 2-4.
} 
Christians to study? Determining which ideas could be incorporated and facing direct challenge to the abiding world view was of paramount importance. Alchemy's reduction from pre modern scientific pursuit to pseudoscience and possibly magic occurs in this process. Because of Alfred of Sarashel's translation, for almost the entirety of this century Ibn Sina's attack on alchemy was believed to belong to Aristotle. In this age Aristotle was considered the prince of philosophers and his often disconcerting theories occupied a central space in the debate of the transmission process. Due to translation error, so did Alchemy.

Aristotle's theories were not comfortable for the Christian scholar to digest. Aristotle asserted that the universe was eternal, never created or destroyed. The soul was destroyed with the body at death and god in his universe was quite unlike the Christian God. The prime mover as he referred to it, is unaware of the existence of individual humans and incapable of intervening. While the prime mover does not affect human affairs, the movement of the stars can. These theories eliminate the possibility of miracles, God-given free will, divine providence, an afterlife, in addition to contradicting the creation story in Genesis. Aristotle presented an awkward dilemma for the thirteenth-century scholar and church alike. These ideas were the source of no small anxiety. Nonetheless the vast corpus and fame of Aristotle was irresistible. In consideration of the scientific materials available prior to the translation movement, which was largely Isidore's Etymologies and similar encyclopedic volumes, Aristotle's writings on nearly every subject were too practical and too tempting to reject. Professors began to teach Aristotle's theories in the universities. For some professors the wisdom of pagan classic texts was superior to possible biblical contradiction. Some professors invited students to hold Aristotle and the church in suspension with each other, accepting that they could both be true and irreconcilable. 
Some even went so far as to teach that Aristotle was to be accepted wholesale without consideration of church teaching. ${ }^{100}$

More conservative members of the faculty at the University and Alumni within the church became concerned, and in 1270 the Bishop of Paris, Etienne Tempier, issued condemnations banning Aristotelian teachings. In 1231 Pope Gregory IX became personally involved, writing in a decree to the university: "Those books on natural philosophy which for a certain reason were prohibited in a provincial council, are not to be used at Paris until they have been examined and purged of all suspicion and error...In the schools they shall dispute only on such questions as can be determined by theological books and the writings of the holy fathers." ${ }^{\prime 101}$ In 1277, the bishop of Paris in concert with the theology department banned further texts, 219 in all, including some accepted by Thomas Aquinas. The ban was short-lived. The benefits of teaching the material and the difficulty associated with sifting through it proved too great. ${ }^{102}$ This episode illustrates the power of the anxiety about novel ideas during this period, and how deeply interested scholars and theologians of Christendom were from the pope to the university professor. Some scholars have even marked this as the beginning of the scientific revolution. ${ }^{103}$ Whether or not this is an anachronism it is inescapable that the question of God as opposed to science, and science as opposed to magic, was a pressing one and the debate attracted the great minds of the century into a vast literary conversation, reading and commenting on the texts of the church fathers, the new translations, and each other.

100 Lindberg, The Beginnings of Western Science, 218-224.

${ }^{101}$ Statutes of Gregory IX, ed, Tierney, Sources of Medieval History, 292.

${ }^{102}$ Lindberg, The Beginnings of Western Science, 216-218.

${ }^{103}$ Steven P. Marrone, "Magic and the Physical World in Thirteenth-Century Scholasticism," Early Science and Medicine 14 (2009):158-85. 
The novelty of the translation movement exceeded of course the works of Aristotle. It yielded advances in medicine, astronomy, mathematics, agriculture, philosophy and an influx of what would be called the occult or magic arts, necromancy, pyromancy, hydro and geomancy, astrology, and other forms of soothsaying and magic. Knowledge of magic and attempting to tell the future by the stars or speak to the dead was of course nothing new. ${ }^{104}$ Magic is older than can be faithfully detailed here, and Christian writings on the subject stretch back to St. Augustine and Isidore of Seville. What was heretical and superstitious was defined as the church centralized and codified its beliefs throughout the medieval period. ${ }^{105}$ To the modern eye, all medieval belief may appear superstitious but this is a suffocating anachronism. The teachings and doctrine of the church provided guidelines. Worship of a deity outside the Christian God or attempting to possess powers of fortune telling, reading the stars, speaking to spirits, or anything else deemed outside the natural allotted abilities of man was heretical. The inception of so many texts on magic and things like magic alongside scientific texts forced Latin theologians to define the parameters of not only magic but the power of demons and the devil. Roger Bacon described the preoccupation and neatly summarized the dispute when he said, "many books are held to be magical which are not really so, but which contain important truths, which are of this kind and which are not, it is for the wise man to decide."106 Bacon's opinion is exemplary of a more theologically liberal camp of scholars intrigued by the possibility of the new sciences. Conversely, some scholars were profoundly concerned about the possibilities of increases and new forms of heresy.

\footnotetext{
${ }^{104}$ Discussion of various kinds of magic in medieval thought can be found as far back as Isidore of Seville (CE 560636), William E. Klingshirn, “Isidore of Seville's Taxonomy of Magicians and Diviners.” Traditio 58 (2003): 59-90. 105 Alan Charles Kors and Edward Peters, Witchcraft in Europe, 400-1700: A Documentary History, 2 nd ed. (Philadelphia: University of Pennsylvania Press, 2001), 6-16.

106 John H. Bridges, trans., The “Opus Majus” of Roger Bacon (Oxford: Clarendon Press. 1900), lxxvii.
} 
In this conversation the work of the theologian Peter Lombard came to considerable utility. Peter's Sentences was composed just previous to the renaissance in the late twelfth century, and gained immediate popularity. ${ }^{107}$ It was a collection of questions and answers on various topics of theology. In book 2 distinction 7, Peter argues that "the magic arts work by means of the power and knowledge of the devil, which power and knowledge is granted to him by God." ${ }^{108}$ He bases this idea on the solid foundation of the story of Pharaoh's magi in Exodus. The snakes made manifest by Pharaoh's magi and their subsequent failure in the seven plagues of Egypt are inferred to prove that magic is an illusion permitted as God wills it, no real transformation takes place because the demons the magi take their power from cannot be creators as God is.

In the 1240 s, Albertus Magnus composed a commentary on this the Sentences, as many scholars following him would do. Critically, he incorporates alchemy in his response to Peter's theory of magic arts and the power of demons. Albert proposes a series of possibilities, for and against the powers of demons and magic. First he writes, "art does not transmute substantial form into [another substantial] form, because Aristotle says in Meteorology IV that "the artificers of alchemy should know that species cannot be transmuted; therefore, demons cannot [transmute them], because they work only by means of art." ${ }^{109}$ The resonating effect of Alfred of Sarashel's error is made plain here. If Albertus Magnus had not believed Ibn Sinna's attack on alchemy to be Aristotle's, it would not have made for such compelling evidence for his argument. Albertus then argues in the affirmative for the power of magic, presenting contrasting arguments in traditional scholastic style. He relies on an Augustinian notion that demons can answer the

\footnotetext{
${ }^{107}$ Haskins, The Renaissance of the Twelfth Century, 49, 82, 215.

${ }^{108}$ Kors and Peters, Witchcraft in Europe, 400-1700, 104-105; Newman, Promethean Ambitions: Alchemy and the Quest to Perfect Nature, 45.

${ }^{109}$ Newman, Promethean Ambitions: Alchemy and the Quest to Perfect Nature, 45-46.
} 
incantations of sorcerers and appear to create through supernatural speed and knowledge. They can collect "seminal reasons," something like seeds of creation distributed around the world, and assemble them with greater speed than human beings can perceive. As he has established that like man, demons work in the power of art (or technical ability), Albertus says, "Therefore it seems that if the power of art worked in the transmutations of bodies, as in alchemy, that demons would be able to do this much more powerfully." 110 Albertus Magnus was the first, but not the last, to use alchemy as a measure for the power of demons and magic, a position that would prove precarious as the debate for the power of God as opposed to science, God as opposed to demons, and science as opposed to magic continued.

Another early legal text, written in the tenth century, came to enjoy a new relevance and particular significance in the debate. The Canon Episcopi expressed a skeptical view of magic typical of the period of its composition. The text expressly condemns a popular belief at the time, that heretical women worship the goddess Diana and are transported long distances and occasionally change shape. Space does not allow for a discussion of this particular belief and its place in the history of witchcraft. What is important is the response of the Canon Episcopi to the belief in any force but God possessing the power of shapeshifting. "Whoever believes any created thing to be able to be made or to be changed into better or worse or transmuted into another shape (speciem) or likeness, except by the Creator...is without doubt an infidel and worse than a pagan."111 This text was a part of cannon law and like the sentences, was widely distributed across the Latin world inspiring commentary. By the late thirteenth century, the

\footnotetext{
${ }^{110}$ Ibid., 47.

${ }^{111}$ Newman, Promethean Ambitions: Alchemy and the Quest to Perfect Nature, 55-56.
} 
Dominican chronicler Martinus Polonus reiterated the argument of the Canon, specifically including alchemy. ${ }^{112}$

In 1487, alchemy was again utilized in the condemnation of occult practices and beliefs. The Malleus Maleficium is variously translated as Hammer of Witches of Hammer of Heretics. In either case the meaning is rather clear; it is intended as a militant response to witchcraft and heresy. Along with some rather interesting assumptions about the weak and insidious nature of women, there is a brief treatment of alchemy. In the introduction, the Malleus Maleficium continues the trend of using alchemy as a benchmark for the power of demons.

We may put forward the opinion of S. Thomas when he discusses the power of the devil and how he works: Although certain forms having a substance may be brought about by art...this cannot be done universally... and thus alchemists make something similar to gold, that it to say, in so far as the external accidents are concerned, but nevertheless they do not make true gold...this then is our proposition, devils by their art do bring about evil effects through witchcraft... ${ }^{113}$

The Mallus Malcifirum remained influential for centuries after its composition, as did the work of Albertus Magnus, Thomas Aquinas, and Roger Bacon. The alchemists we met in the beginning were accused of sorcery, of charms and spells to make themselves invisible, a claim that was easy to adhere to them and perfectly believable. The Malleus Maleficarum and similar documents previously explored illuminate how Alchemy transformed from a science occasionally criticized or contested but practiced unmolested, as it was in its previous iterations, ${ }^{114}$ to one that had a powerful association with demons and heresy. The image of the

\footnotetext{
${ }^{112}$ Ibid., 56.

${ }^{113}$ Heinrich Institoris, Jakob Sprenger, and Montague Summers, Malleus Maleficarum (New York: B. Blom, 1970) 11.

${ }^{114}$ Though the criticism of alchemy was translated from the Arabic, it did not have the same dramatic effect in its original context. Alchemists were always criticized for fear that their work would destabilize the economy, or that they promised more than they could deliver. Principe, The Secrets of Alchemy, 47-50.
} 
alchemist as a potentially dangerous charlatan was born. The minutiae of the translation movement with its sociopolitical influences and the resultant concern about new translations yields still another avenue for the defamation of alchemy.

During the crusades Islam acquired a powerful association with magic and of course, the devil. Perhaps thanks to the centuries of Islamic occupation, Spain possessed a coincident reputation in the wider Latin world as a bastion of black magic. ${ }^{115}$ Polemics and propaganda from the crusades and Reconquista produced descriptions of Mohammed as a sorcerer, using spells and supernatural trickery to seduce his converts. ${ }^{116}$ The reader may remember alchemical texts were translated in Spain during the crusades and Reconquista and retained its Arabic heritage with the Arabic definite article al. Alchemy's conspicuous heritage and alchemists habit of writing in cryptic allegory form an unfortunate dovetail with the sociopolitical mechanisms of the twelfth-century translation movement. As has been succinctly explored previously, errors and imprecisions in translation had profound implications. While Robert of Chester was the first to translate a complete alchemical text, there is evidence it was not the first percolation of alchemical ideas into the Latin world.

Scholars still debate the exact date of its publication, but sometime between 1100 and 1120 a treatise entitled On Divers Arts was written under the pen name Theophilus Presbyter. The real name of the author and where it was written remains under debate. ${ }^{117}$ All the same, the author's unusually frank, practical, and technologically skilled treatment of various artisanal techniques has kept it popular to the present day with multiple editions and printings. ${ }^{118}$ Tucked

\footnotetext{
115 Haskins, Studies in the History of Mediaeval Science.

${ }^{116}$ Chronicon mundi, ed. Colin Smith, C. P. Melville, and Ahmad 'Ubaydlī, Christians and Moors in Spain, 2-3.

117 John G. Hawthorne, Cyril Stanley Smith, and Jay I. Kislak, On Divers Arts; the Treatise of Theophilus (Chicago: University of Chicago Press, 1963) xv-xvii.

${ }^{118}$ Ibid., Xvi-xxix.
} 
away in the third book, nestled in with various pragmatic descriptions of various kinds of metals and how to use them for artisanal purposes, there is one chapter which is unlike the others. In one chapter entitled "Spanish Gold," Theophilus describes something quite fantastic. "There is also a gold named Spanish gold, which is compounded from red copper, basilisk powder, human blood, and vinegar. The heathens, whose skill is quite commendable, create basilisks for themselves." Theophilus goes on to describe a detailed procedure beginning with locking two cocks in a dungeon underground. They are to be overfed until they copulate and lay the eggs of the insidious creature. This is all done underground because Basilisks can of course kill with a glance. The cocks are removed at this stage and replaced with toads to hatch the eggs. The chicks which emerge from these eggs sprout serpent's tails. Eventually the monsters are incinerated, their ashes are ground up and mixed with the blood of a red headed man and tempered with vinegar. The finest copper is to be obtained and coated in this concoction then subjected to fire several times, until "the composition eats through the copper, which thereby acquires the weight and quality of gold." 119 This description should sound familiar to the allegorical twelve keys of Basil Valentine and the more pragmatic recipes of Geber explored previously.

To all appearances this is a case of alchemical allegory taken literally by a scholar and an artisan unfamiliar with both the art and Arabic. An alchemical recipe has recently been unearthed in Arabic which is thought to be the source of the recipe for Spanish gold. ${ }^{120}$ In the introduction of his work Theophilus proudly assures the reader he has gathered recipes from around the world, increasingly the probability that the author either traveled to or received from a scholar

\footnotetext{
119 Hawthorne, Smith, and Kislak, On Divers Arts; the Treatise of Theophilus, 119-20.

${ }^{120}$ Chet Van Duzer, “An Arabic Source for Theophilus's Recipe for Spanish Gold," Zwischen Kunsthandwerk und Kunst (2014): 369-378
} 
there an alchemical recipe translated from the Arabic as a novelty in metal working, a wonder from the heathens of Spain incorporated in an otherwise practical manual for its exoticism. ${ }^{121}$

One of the consequences of alchemical allegory losing its nuances to translation is the increased probability that it could be confused with occult and magic texts. An occult procedure is presented below which presents itself as one that will enable those who can stomach it to see spirits:

... a white cock with a round crest which is concave in the middle is put in a place were neither the bark of a dog nor the voice of a crow is heard...For three successive days the cock is to be fed on the eyes of three fish of the species known as alliataiu, and the eyes must have been removed while the fish were still living...he is to be decapitated and fed to a wild cat, which is then to be beheaded in its turn. Its blood and gall are to dried and from them a concoction is to be prepared which will enable one to see spirits. ${ }^{122}$

Both texts present a ritualistic utilization of animals (namely cocks), blood, and ashes.

This second text is, however, a relative how-to for a particular mode of sorcery found in a book entitled Liber Vaccae. It was commonly ascribed to Galen or Plato and appears in works by thirteenth-century Latin scholars writing disapprovingly of magic arts. ${ }^{123}$ A modern eye familiar with alchemical symbolism can tell the difference between the two recipes, chiefly by the knowledge that Theophilus' recipe is an allegory out of context. The same discernment was likely out of reach for medieval eyes unfamiliar with alchemical literary style, but acutely familiar with rumors about occult activity in Spain and the treatment of alchemy in the work of Albertus Magnus or the Malleus Maleficium.

\footnotetext{
${ }^{121}$ Principe discusses this theory and possible implications of this translation in some detail. Principe, The Secrets of Alchemy, 53-55.

122 Thorndike, History of Magic and Experimental Science, vol. 2, 781.

${ }^{123}$ Thorndike, History of Magic and Experimental Science, 777-80.
} 
Though further research is needed on this topic, this much can be said with the scholarship available: the sociopolitical mechanisms that facilitated the twelfth century translation movement colored alchemy for the rest of its life. The influx of Arabic scholarship as well as the fruits of Alexandria and Athens in one century after centuries of relative intellectual darkness should be considered nothing short of a revolution. The newly amassed masses of pagan ideas had to be assimilated or eliminated, and the possibility of change in traditional Christian dogma calculated. For so weighty a task, scholars and theologians relied on church fathers when they could. Augustine and Peter Lombard at first, by the close of the century Albertus Magnus and Thomas Aquinas had risen to that rank and brought alchemy within the fold of the conversation in a most unflattering light. In the beginning of the century just after its translation, alchemical writing had largely dispensed with allegory and was in some universities incorporated into the curriculum. When the social and intellectual climate turned cold to alchemy, allegory resurfaced and the use of pseudonyms with it. ${ }^{124}$ A protective strategy designed to provide anonymity and authority, using the case of Theophilus to infer the consequences of this approach it appears to have backfired.

Despite alchemy's unfortunate classification as impossible at the beginning of the Latin scientific conversation, the practice did not die out but continued just out of sight of prying eyes. It progressed and eventually the experiments performed by alchemists, the techniques and materials yielded in some ways paved the way for modern chemistry. ${ }^{125}$ It is interesting to imagine what it might have been like if it had not acquired this association so soon, or at all. The association was only built on in subsequent centuries, and is now inescapable. Typing magic into

\footnotetext{
124 Principe, The Secrets of Alchemy, 62-63.

${ }^{125}$ Principe, "Alchemy Restored," Isis 102, no. 2 (2011): 305-12.
} 
thesaurus.com will yield a wealth of synonyms, and invariably alchemy will be listed among them. Alchemy's promise to supersede nature and provide man with the ability to unravel her secrets was too tempting, too suited to the nature of science itself. The continual influence, the suspicion, the conflict, and the enduring allure for scientists is evident in the discovery of Nuclear transmutation in 1901 by Fredrick Soddy and Earnest Rutherford. At the moment of their discovery, in his exuberance Soddy blurted "Rutherford! This is Transmutation: the thorium is disintegrating and transmuting itself into an argon gas," to which Rutherford responded, "for Mike's sake Soddy, don't call it Transmutation. They'll have our heads off as alchemists."126

\section{Bibliography}

Abdurrahman Badawi. "The Toledo School. (Translators in Toledo, Spain during the Moorish Rule) (Al-Andalus: Where Three Worlds Met).” UNESCO Courier (1991): 40.

Al-hassan, Ahmad Y. "the Arabic Original of Liber de Compositione Alchemiae" The Epistle of Marynus, the Hermit and Philosopher, to Prince Khlid Ibn Yazd." Arabic Sciences and Philosophy 14, no. 2 (2004): 213-31.

Badash, Lawrence. "How the 'Newer Alchemy' Was Received." Scientific American 215, no. 2 (1966): 88-95.

Barraclough, Geoffrey. The Medieval Papacy. 1st American ed. (New York: Harcourt, Brace \& World, 1968).

Barton, Simon. Conquerors, Brides, and Concubines: Interfaith Relations and Social Power in Medieval Iberia. (Philadelphia: University of Pennsylvania Press, 2015).

${ }^{126}$ Lawrence Badash, “How the 'Newer Alchemy’ Was Received,” Scientific American 215 (1966): 88-95. 
Berk, M. F. M. Van Den. The Magic Flute, Die Zauberflöte: An Alchemical Allegory. (Leiden; Boston: Brill, 2004).

Bridges, John H., trans. The “Opus Majus” of Roger Bacon. (Oxford: Clarendon Press, 1900).

Burnett, Charles. "The Coherence of the Arabic-Latin Translation Program in Toledo in the Twelfth Century." Science in Context 14, no. 1-2 (2001): 249-88.

Chism, Christine. "Arabic in the Medieval World.” PMLA 124 (2009): 624-31.

Chevedden, Paul E. "The View of the Crusades from Rome and Damascus: The Geo-Strategic and Historical Perspectives of Pope Urban II and 'alī Ibn Ṭāhir Al-Sulamī.” Oriens 39 (2011): 257-32.

Constable, Olivia Remie, and Damian Zurro. Medieval Iberia: Readings from Christian, Muslim, and Jewish Sources. 2nd ed. Middle Ages Series. (Philadelphia: University of Pennsylvania Press, 2012).

Duncan, Edgar H. "The Literature of Alchemy and Chaucer's Canon's Yeoman's Tale: Framework, Theme, and Characters." Speculum 43, no. 4 (1968): 633-56.

Ferrario, Gabriele. “An Arabic Dictionary of Technical Alchemical Terms: MS Sprenger 1908 of the Staatsbibliothek Zu Berlin (fols. 3r-6r).” Ambix 56, no. 1 (March 2009): 5-48.

Glick, Thomas F. Islamic and Christian Spain in the Early Middle Ages. (Princeton, N.J.: Princeton University Press, 1979).

Haskins, Charles Homer. Studies in the History of Mediaeval Science. (New York: Ungar, 1960)

Haskins, Charles Homer. The Renaissance of the Twelfth Century. (New York: Meridian Books, 1957).

Hawthorne, John G. Smith, Cyril Stanley, and Jay I. Kislak. On Divers Arts; the Treatise of Theophilus (Chicago: University of Chicago Press, 1963).

Holmyard, E. J. The Works of Geber. (London and Toronto: J. M. Dent; New York: E. P. Dutton, 1928).

Ibn Al-Nadīm, Muhammad Ibn Isḥāq, trans. Bayard Dodge. The Fihrist of Al-Nadīm; a TenthCentury Survey of Muslim Culture. (New York: Columbia University Press, 1970)

Institoris, Heinrich, Sprenger, Jakob, and Summers, Montague. Malleus Maleficarum. (New York: B. Blom, 1970).

Klingshirn, William E., "Isidore of Seville's Taxonomy of Magicians and Diviners." Traditio 58 (2003): 59-90.

Kors, Alan Charles, and Peters, Edward. Witchcraft in Europe, 400-1700: A Documentary History. 2nd ed. (Philadelphia: University of Pennsylvania Press, 2001).

Latham, Andrew A., "Theorizing the Crusades: Identity, Institutions, and Religious War in Medieval Latin Christendom.” International Studies Quarterly 55 (2011): 223-43. 
Lindberg, David C., The Beginnings of Western Science: The European Scientific Tradition in Philosophical, Religious, and Institutional Context, Prehistory to A.D. 1450. 2nd ed. (Chicago: University of Chicago Press, 2007).

Linden, Stanton J. The Alchemy Reader: From Hermes Trismegistus to Isaac Newton. (Cambridge: Cambridge University Press, 2003).

Marrone, Steven P. "Magic and the Physical World in Thirteenth-Century Scholasticism." Early Science and Medicine 14, no. 1/3 (2009): 158-85.

Márquez-Villanueva, Francisco. "Ways and Means of Science in Medieval Spain.” European Review 16, no. 2 (2008): 145-157.

Newman, William R. The Summa Perfectionis of Pseudo-Geber: A Critical Edition, Translation and Study. (Leiden; New York: E. J. Brill, 1991).

Newman, William R. Promethean Ambitions: Alchemy and the Quest to Perfect Nature. (Chicago: University of Chicago Press, 2004).

Newman, William R., and Lawrence M. Principe. "Alchemy vs. Chemistry: The Etymological Origins of a Historiographic Mistake." Early Science and Medicine 3, no. 1 (1998): 3265.

Nummedal, Tara. Alchemy and Authority in the Holy Roman Empire. (Chicago: University of Chicago Press, 2008).

Principe, Lawrence. The Secrets of Alchemy. (University of Chicago Press. Chicago; London, 2013).

Principe, Lawrence M. "Alchemy Restored." Isis 102, no. 2 (2011): 305-12.

Reilly, Bernard F. The Contest of Christian and Muslim Spain : 1031-1157. History of Spain. (Cambridge, MA: Blackwell, 1992).

Reti, Ladislao. "Parting of Gold and Silver with Nitric Acid in a Page of the Codex Atlanticus of Leonardo Da Vinci." Isis 56, no. 3 (1965): 307-19.

Saliba, George. Islamic Science and the Making of the European Renaissance. (Cambridge, Mass: MIT Press, 2007).

Scott L. Montgomery, Science in Translation: Movements of Knowledge through Cultures and Time. (Chicago: University of Chicago Press, 2000).

Smith, Colin, C. P. Melville, and Aḥmad 'Ubaydlī. Christians and Moors in Spain. (Warminster, England: Aris \& Phillips, 1988).

Smith, Pamela H. The Business of Alchemy : Science and Culture in the Holy Roman Empire. (Princeton, N.J.: Princeton University Press, 1994).

Taylor, Gail, and Jochen Burgtorf. "Al-Rāzì's "Book of Secrets": The Practical Laboratory in the Medieval Islamic World” (Masters thesis, California State University, Fullerton, 2008)

Taylor, Sherwood F. The Alchemists. (New York: Collier Books, 1962). 
Thorndike, Lynn. A History of Magic and Experimental Science. v II (New York: Columbia University Press, 1923).

Tierney, Brian. Sources of Medieval History. 4th ed. (New York: Knopf, 1983).

Yücesoy, Hayrettin. "Translation as Self-Consciousness: Ancient Sciences, Antediluvian Wisdom, and the 'Abbāsid Translation Movement." Journal of World History 20, no. 4 (2009): 523-57. 